\title{
Skin and Psyche - Closing the Gap
}

This editorial is probably the most difficult one I have written recently. When this journal was started full of aspiration in the year 2000, there was a spirit of new life in the Karger Publishing House. 'Skin and Psyche - Closing the Gap' [Augustin et al., 2000] was the title of the very first editorial with which we welcomed our readers to the journal. With this title we also wish to conclude with it.

In today's world of media and means of communication times are hard for a scientific journal that only covers a limited area - such as psychodermatology. Nearly every day new journals are set up whereas others are discontinued. Unfortunately, Dermatology + Psychosomatics is one of the latter. With this issue, publication of the journal will cease. Although the journal has been well established among the European Society for Dermatology and Psychiatry (ESDaP), the Société Francophone de Dermatologie Psychosomatique (SFDP) in France and the Arbeitskreis Psychosomatische Dermatologie (APD) in Germany, and has been widely recognized in the scientific community, we could not secure its financial basis. When we made the first issue that comprised articles on psychosocial factors of melanoma [Zschocke et al., 2000], on observations during an itch lecture [Niemeier et al., 2000], and a case report by Brosig et al. [2000] on atopic dermatitis, we wanted to provide a platform for scientific exchange on this important but neglected subject. You have probably noticed that other international journals like the 'British Journal of Dermatology, the Archives of Dermatology, the JEADV, and the Journal of the American Academy of Dermatology have constantly been publishing articles on psychodermatological topics over the past years. These journals have discovered 'our' topic and partly present it special sections. This should be regarded as a positive development reflecting that psychodermatologic issues are increasingly perceived in the field of somatically-oriented dermatology and are investigated scientifically. We have just held various symposiums at the EADV congress in Florence and they attracted many interested listeners. An increasing number of dermatologists shows interest in this particular field, and the studies presented were all of high quality and practical relevance.
The editors-in-chief of Dermatology + Psychosomatics regret the end of the journal. We wish to thank Karger publishers and the editorial office that have shown huge commitment to the journal in its 5 years of existence. We also thank the members of the editorial board and everyone else without whom this peer-reviewed journal would never have been possible. Last but not least, we wish to thank our readers and the members of the psychodermatological societies that kept faith with the journal over the last 5 years - it was you who contributed to the journal's success and popularity.

We are currently developing new ideas and ways how to further communicate and distribute psychodermatological issues and hope to present you details in the near future. For the time being, a new platform will be made available on the ESDaP homepage, www.psychodermatology.info.

We truly hope you will keep in touch with information, opinions, letters to the editors and articles, so we can assure the future of psychodermatology. With this last issue of DERMATOLOGY + PSYCHOSOMATICS published by Karger we wish all our readers a merry Christmas and a satisfying conclusion of the year 2004 !

Uwe Gieler, Gießen

Françoise Poot, Brussels Gerhard Schmid-Ott, Hannover Ina Zschocke, Freiburg i.Br.

\section{References}

Augustin M, Cotterill J, Gieler U, Zscocke I: Skin and psyche - closing the gap. Dermatol Psychosom 2000;1(suppl 1):4-5.

Brosig B, Kupfer J, Köhnlein B, Niemeier V, Gieler U: Atopic dermatitis in psychoanalytic psychotherapy - a psychobiological case study. Dermatol Psychosom 2000;1(suppl 1):19-26.

Niemeier V, Kupfer J, Gieler U: Observations during an itch-inducing lecture Dermatol Psychosom 2000;1(suppl 1):15-18.

Zschocke I, Rhein J, Grimme H, Stein B, Muthny FA, Augustin M: Self-examination of patients with mailgnant melanoma in the aftercare: Relevance of psychosocial factors and instructions by the physicians. Dermatol Psychosom 2000;1(suppl 1):8-14.

\begin{tabular}{llll}
\hline KARGER & ( 2004 S. Karger GmbH, Freiburg & & Prof. Dr. Uwe Gieler \\
Fax +49 761 4520714 & Accessible online at: & & Justus-Liebig-Universität Gießen \\
E-mail Information@Karger.de & www.karger.com/dps & Klinik f. Psychosomatik u. Psychotherapie \\
www.karger.com & & Ludwigstraße 76, D-35392 Gießen \\
& & Tel. +49 641 99-45651, Fax -45659 \\
& & E-mail Uwe.Gieler@psycho.med.uni-giessen.de
\end{tabular}

